\title{
A Study on Eye Movement in Reading English and Uyghur Exposition by Uyghur College Students
}

\author{
Hongzhi Yu \\ Key Lab of China's National \\ Linguistic Information Technology, \\ Northwest University for \\ Nationalities \\ KLCNLIT,NUN \\ Lanzhou, China \\ email: yuhongzhi@hotmail.com
}

\author{
Yaqin Zhang \\ Key Lab of China's National \\ Linguistic Information Technology, \\ Northwest University for \\ Nationalities \\ KLCNLIT,NUN \\ Lanzhou, China
}

email: 24172435@qq.com

\author{
Dongxu Zhang* \\ Key Lab of China's National \\ Linguistic Information Technology, \\ Northwest University for \\ Nationalities \\ KLCNLIT,NUN \\ Lanzhou, China \\ email:idolleehom@163.com
}

\begin{abstract}
By the eye movement technique, we use the Eyelink- II tracker to record the eye movements of 10 Uyghur college students with different English level. They are asked to read English and Uyghur Exposition. The results showed eye movement indexes in reading Uyghur and English expositions by the Uyghur college students, eye movement indexes of Uyghur expositions are higher than that of English expositions, but with the improvement of their English level, there is little difference between them.
\end{abstract}

Keywords-Uyghur College Students; English and Uyghur Exposition; Study on Eye Movement

\section{INTRODUCTION}

Reading comprehension is an important cognitive activity of the human society, in the meantime it plays a key role in acquiring knowledge and knowing the world. Linguistics, psychology and pedagogy study the reading comprehension all the time. English is an international language. This paper uses the EyeLink- II tracker to record the eye movements that are about reading English and Uyghur expositions of 10 Uyghur University Students, our aim is to provide eye movement parameters so as to know about some external rules and patterns in reading ,in this way, it can help Uyghur college students to improve English reading level.

\section{RESEARCH METHODS}

\section{A. Subjects}

Select 10 Uygur college students, 5 of them passed College English Test Band 4, the others didn't pass it.

\section{B. Experiment Apparatus}

This experiment uses $\mathrm{Hi}$ - speed eye-movement apparatus that is made by German SMI Company.

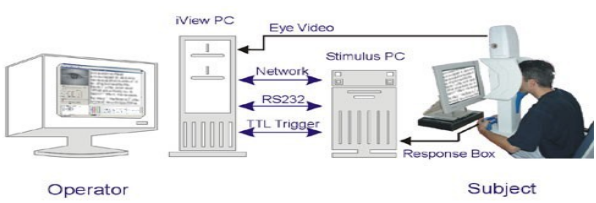

Figure1: Flow Chart of Collecting Eye MOVEMENT SignAL

C. Experiment Materials

Select 5 English expositions and 5 Uygur expositions

D. Explanation

(1)Reading Time: the time of reading an article.

(2)Reading Speed: the number of reading words per unit time.

(3)Fixation Duration: the number of fixation point in the entire article.

(4)Fixation Duration Average: average gaze time of each fixation point.

(5)Fixation Frequency: the number of fixation point per unit time.

6) Saccade Amplitude: an index of the perceptual span in reading.

(7) Saccade Count: the number of saccade of the entire article.

(8) Saccade Frequency: the average number of saccade per unit time.

(9) Saccade Duration: a fixation point moves to the next fixation point.

\section{EXPERIMENTAL RESULTS AND ANALYSIS}

This paper studies Uyghur college students who are different English level how to understand English、 Uyghur exposition through seven saccade indexes. 


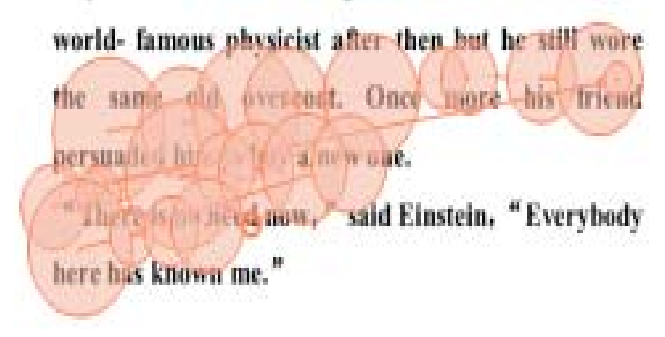

FIGURE2: TRAJECTORY GRAPH OF EYE MOVEMENT

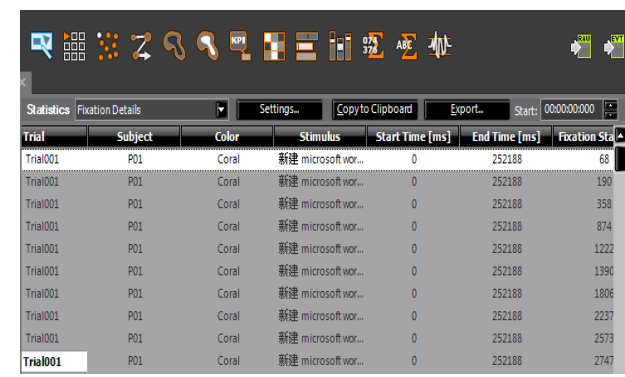

FIgURE3: COLLECT EYE MOVEMENT PARAMETERS THOUGHT BEGAZE SOFTWARE

\section{A. Reading Parameters}

TABLE1: THE COMPARISON OF READING PARAMETERS OF UYGHUR COLLEGE STUDENTS OF LOW ENGLISH LEVEL

\begin{tabular}{|c|c|c|c|c|c|c|c|}
\hline \multirow{2}{*}{ Level } & \multirow{2}{*}{$\begin{array}{c}\text { Reading } \\
\text { Parameters }\end{array}$} & \multicolumn{3}{|c|}{$\begin{array}{c}\text { English } \\
\text { Exposition }\end{array}$} & \multicolumn{4}{c|}{$\begin{array}{c}\text { Uyghur } \\
\text { Exposition }\end{array}$} \\
\cline { 3 - 8 } & $\mathrm{N}$ & $\mathrm{M}$ & $\mathrm{SD}$ & $\mathrm{N}$ & $\mathrm{M}$ & $\mathrm{SD}$ \\
\hline \multirow{3}{*}{ Low } & $\begin{array}{c}\text { Reading } \\
\text { Time }\end{array}$ & 5 & 894.2 & 87.1 & 5 & 68.7 & 18.6 \\
\cline { 2 - 8 } & $\begin{array}{c}\text { Reading } \\
\text { Speed }\end{array}$ & 5 & 0.15 & 0.09 & 5 & 1.92 & 0.87 \\
\hline
\end{tabular}

Table1 show Uyghur College students who are low English levels read English 、Uyghur expositions, reading time and reading speed are different. Uyghur reading parameters are much higher than English reading parameters. This indicates that Uyghur college students are affected by mother tongue, in addition their English is poor, so it is very difficult for them to read English.

TABLE2: THE COMPARISON OF READING PARAMETERS OF UYGHUR COLLEGE STUDENTS OF HIGH ENGLISH LEVEL

\begin{tabular}{|c|c|c|c|c|c|c|c|}
\hline \multirow{2}{*}{ Level } & \multirow{2}{*}{$\begin{array}{c}\text { Reading } \\
\text { Parameters }\end{array}$} & \multicolumn{3}{|c|}{$\begin{array}{c}\text { English } \\
\text { Exposition }\end{array}$} & \multicolumn{4}{c|}{$\begin{array}{c}\text { Uyghur } \\
\text { Exposition }\end{array}$} \\
\cline { 3 - 8 } High & $\begin{array}{c}\text { Reading } \\
\text { Time }\end{array}$ & 5 & 134.4 & 22.3 & 5 & 48.6 & 10.5 \\
\cline { 2 - 8 } & $\begin{array}{c}\text { Reading } \\
\text { Speed }\end{array}$ & 5 & 0.98 & 0.17 & 5 & 2.72 & 1.56 \\
\hline
\end{tabular}

Table2 show Uyghur College students who are high English levels read English 、Uyghur expositions, there is no difference in reading time and reading speed. With the improvement of English level, results of English exposition are close to results of Uyghur exposition, this is to say they increase English proficiency step by step.

\section{B. Fixation Parameters}

TABLE3: THE COMPARISON OF FIXATION PARAMETERS OF UYGHUR COLLEGE STUDENTS OF LOW ENGLISH LEVEL

\begin{tabular}{|c|c|c|c|c|c|c|c|}
\hline \multirow{2}{*}{ Level } & Fixation & \multicolumn{3}{|c|}{ English exposition } & \multicolumn{3}{|c|}{ Uyghur Exposition } \\
\cline { 3 - 8 } & parameters & $\mathrm{N}$ & $\mathrm{M}$ & $\mathrm{SD}$ & $\mathrm{N}$ & $\mathrm{M}$ & $\mathrm{SD}$ \\
\hline \multirow{3}{*}{ Low } & $\begin{array}{c}\text { Fixation } \\
\text { count }\end{array}$ & 5 & 336 & 43.2 & 5 & 53 & 8.8 \\
\cline { 2 - 8 } & $\begin{array}{c}\text { Fixation } \\
\text { Average }\end{array}$ & 5 & 422 & 49.8 & 5 & 176 & 18.9 \\
\cline { 2 - 8 } & $\begin{array}{c}\text { Fixation } \\
\text { Frequency }\end{array}$ & 5 & 2.0 & 0.38 & 5 & 2.56 & 0.45 \\
\hline
\end{tabular}

Table3 shows Uyghur College students who are low English levels read English 、Uyghur expositions, their Uyghur fixation parameters are higher than English fixation parameters, because Uyghur college students of low English level are affected by mother tongue, they have high Uyghur proficiency, in a word fixation frequency is high ,however, fixation duration is low. Meanwhile, fixation parameters implies that fixation count and fixation duration relate to the proficiency of the article on subjects.

TABLE4:THE COMPARISON OF FIXATION PARAMETERS OF UYGHUR COLLEGE STUDENTS OF HIGH ENGLISH LEVEL

\begin{tabular}{|c|c|c|c|c|c|c|c|}
\hline \multirow{2}{*}{ Level } & \multirow{2}{*}{$\begin{array}{c}\text { Fixation } \\
\text { parameters }\end{array}$} & \multicolumn{2}{|c|}{ English exposition } & \multicolumn{3}{|c|}{ Uyghur Exposition } \\
\cline { 3 - 8 } & $\begin{array}{c}\text { Fixation } \\
\text { count }\end{array}$ & 5 & 53 & 8.6 & 5 & 53 & 8.6 \\
\cline { 2 - 8 } & $\begin{array}{c}\text { Average } \\
\text { Fixation } \\
\text { Duration }\end{array}$ & 5 & 238 & 19.2 & 5 & 180 & 19.1 \\
\cline { 2 - 8 } & $\begin{array}{c}\text { Fixation } \\
\text { Frequency }\end{array}$ & 5 & 1.6 & 0.32 & 5 & 2.16 & 0.48 \\
\hline
\end{tabular}

Table4 shows that there is no obvious difference in fixation count, fixation duration average and fixation frequency. It implies that with the improvement of English level, the results of reading English exposition are close to that of reading Uyghur exposition, in other words Uyghur college students of high English level improve constantly English Level.

\section{Saccade Parameters}

TABLE 5:THE COMPARISON OF SACCADE PARAMETERS OF UYGHUR COLLEGE STUDENTS OF LOW ENGLISH LEVEL

\begin{tabular}{|c|c|c|c|c|c|c|c|}
\hline \multirow{7}{*}{ Level } & $\begin{array}{c}\text { Saccade } \\
\text { parameters }\end{array}$ & \multicolumn{3}{|c|}{ English exposition } & \multicolumn{3}{|c|}{ Uyghur Exposition } \\
\cline { 3 - 8 } & $\begin{array}{c}\text { Saccade } \\
\text { count }\end{array}$ & 5 & 283 & 18.2 & 5 & 40 & 11.6 \\
\cline { 2 - 8 } Low & $\begin{array}{c}\text { Saccade } \\
\text { Amplitude }\end{array}$ & 5 & 1.2 & 0.51 & 5 & 1.3 & 0.56 \\
\cline { 2 - 8 } & $\begin{array}{c}\text { Saccade } \\
\text { Frequency }\end{array}$ & 5 & 0.5 & 0.06 & 5 & 1.0 & 0.2 \\
\cline { 2 - 8 } & $\begin{array}{c}\text { Saccade } \\
\text { duration }\end{array}$ & 5 & 568 & 37.8 & 5 & 31 & 10.2 \\
\hline
\end{tabular}


Table5 signifies fixation parameters of Uyghur college students of low English Level in reading Uyghur exposition are better than that of Uyghur college students of low English level in reading English exposition, because they are good at Uyghur, saccade amplitude and saccade frequency are high, on the contrary saccade duration is very low. In reading English exposition saccade amplitude gradually reduces, saccade duration increases.

TABLE6: THE COMPARISON OF SACCADE PARAMETERS OF UYGHUR COLLEGE STUDENTS OF HIGH ENGLISH LEVEL

\begin{tabular}{|c|c|c|c|c|c|c|c|}
\hline \multirow{7}{*}{ Level } & Saccade & \multicolumn{3}{|c|}{ English exposition } & \multicolumn{3}{|c|}{ Uyghur Exposition } \\
\cline { 3 - 8 } & parameters & $\mathrm{N}$ & $\mathrm{M}$ & $\mathrm{SD}$ & $\mathrm{N}$ & $\mathrm{M}$ & $\mathrm{SD}$ \\
\hline \multirow{3}{*}{ High } & $\begin{array}{c}\text { Saccade } \\
\text { count }\end{array}$ & 5 & 58 & 17.8 & 5 & 31 & 10 \\
\cline { 2 - 8 } & $\begin{array}{c}\text { Saccade } \\
\text { Amplitude }\end{array}$ & 5 & 1.4 & 0.25 & 5 & 1.3 & 0.56 \\
\cline { 2 - 8 } & $\begin{array}{c}\text { Saccade } \\
\text { Frequency }\end{array}$ & 5 & 0.8 & 0.1 & 5 & 0.9 & 0.3 \\
\cline { 2 - 8 } & $\begin{array}{c}\text { Saccade } \\
\text { duration }\end{array}$ & 5 & 38 & 12.2 & 5 & 31 & 10.2 \\
\hline
\end{tabular}

Table6 reveals that there is no obvious difference in saccade count, saccade duration. saccade amplitude and saccade frequency. It displays that Uyghur college students of high English level improve constantly the proficiency of English because of the improvement of English level.

\section{ANALYSIS AND CONCLUSION}

(1) According to reading parameters, we know that Uyghur College Students of different English Levels have obvious differences in reading same difficult English expositions, but parameters of Uyghur exposition are distinctly higher than that of English exposition. This shows that with the improvement of English level, reading result and reading speed improve, reading time reduce step by step, their English level is close to the level of mother tongue.

(2) In terms of saccade parameters, When Uyghur college students read English expositions that are the same difficulty, saccade count and saccade duration of students of high English level reduce clearly, this shows that they use different ways to read the article. In the face of difficult and unfamiliar articles, students of low English level can increase fixation count, prolong fixation duration, shorten saccade amplitude and extend saccade duration, in order to achieve good results.

In a word, Eye patterns in reading reflect the reader's cognitive processing mode, Uyghur college students of low English level fix constantly in reading English exposition, however, Uyghur college students of high English level make good use of holistic fixation patterns, in this way, they can get good grades in reading. Meantime, it also shows that background education supplements language education. For improving their English level, we should train Uyghur college students scientifically in English teaching.

\section{ACKNOWLEDGEMENT}

This research was financially supported by the State Key Program of National Natural Science of China(61032008).

\section{REFERENCE}

[1] Duffy SA, Keir JA.Violating stereotypes:eye movements and comprehension processes when text confilcts with world knowledge.Men Cofnit,2004,32(4):551-9.

[2] George W M,P ual WK,Michael D R et al. Eye movement control during reading. Frequency of refixation a word Perception and Psychophysics.1989.

[3] Haberlandt'K. Story grammar and reading time of story constituents. Poetics, 1980,9-99-116.

[4] Kemper S,McDowd J, Kramer A.Eye movements of young and older audlts while reading with distraction.Psychol Aging.2006,21(1):32-9.

[5] Laeng B, Teodorescu D-S. Eye scan paths during visual imagery reenact those of perception of the same visual scene. Cognitive Science ,2006,26:207-231.

[6] Marja Vauras. evidence from of eye movement patterns and recall performance, J urnal of Research in Reading 1992,15,39-54.

[7] Wang S, Chen, H-C, Yang J\& Mo, L. Immediacy of integration in discourse comprehension: Evidence form Chinese readers'eye movements Language and Cognitive Processes,2008, 23(2),241-257. 